\title{
Warts and wart virus antibodies in patients with systemic lupus erythematosus
}

\author{
EIJA JOHANSSON, SEPPO PYRHÖNEN, TIMO ROSTILA
}

British Medical fournal, 1977, 1, 74-76

\section{Summary}

Warts were found in 25 out of 56 patients with definite or probable systemic lupus erythematosus (SLE) but in only 19 out of 160 control patients. Warts were particularly prevalent in elderly patients with SLE. The corticosteroid and antimalarial drugs used to treat SLE did not influence the frequency of warts. Wart-virus antibodies were found significantly less often in patients with SLE than in controls: antibodies were detected in 23 out of 51 patients and in 40 out of 54 controls. The findings suggest that some deficiency in the immune mechanisms of patients with SLE predisposes them to develop warts. There was an inverse correlation among the patients with SLE between the occurrence of warts and rheumatoid factor activity. This suggests that rheumatoid factor may interfere with resistance to warts.

\section{Introduction}

It is generally thought that patients with systemic lupus erythematosus (SLE) have an increased susceptibility to infections, and infections have also been considered to be important in triggering SLE. An increased frequency of bacterial and mycotic infections have been reported, ${ }^{12}$ and, on the basis of antibody measurements, SLE is also associated with a few viral infections. High titres against measles, rubella, and Epstein-Barr viruses have been observed, while the antibody response against herpes simplex virus, for example, has been reported to be deficient. ${ }^{3}$ Antibody findings, however, are not good indicators of chronic or recurrent viral infections. Cutaneous herpes and especially wart infections are therefore convenient for research since accurate diagnosis can be based entirely on observation.

During their follow-up many patients with SLE were found to have viral warts. We therefore undertook this study to determine the prevalence of warts and wart-virus antibodies in patients with SLE.

\section{Patients and methods}

The series consisted of 56 unselected patients with definite or probable SLE examined at the deparmtent of dermatology, University Central Hospital, Hensinki, in 1973-5.

Definite or probable SLE was diagnosed on the basis of criteria proposed by the American Rheumatism Association. ${ }^{4}$ The patients were aged 15-78 years old (mean 39.7 years); 50 were women. Many had been under observation for several years. Twelve of them had chronic biological false-positive seroreactions for syphilis.

\footnotetext{
Department of Dermatology, University Central Hospital, Snellmaninkatu 14, Helsinki 17 SF-00170 Finland

EIJA JOHANSSON, MD

TIMO ROSTILA, MD

Laboratory of Viral Immunopathology, Department of Virology, University of Helsinki

SEPPO PYRHÖNEN, MD
}

A control series consisted of consecutive patients either attending the dermatology outpatient department or admitted to hospital for various cutaneous tests. Patients admitted because of warts were excluded from the study. The control group consisted of 30 men and 130 women aged 20 years or more (only one of the patients with SLE was aged under 20 years). Their ages varied from 20 to 66 (mean 37.5 years).

The age distribution of the SLE and control groups did not differ significantly when tested by Student's $t$ test (table I). The incidence of warts in both groups was recorded by one of us. Serum samples were collected from 51 patients and 54 controls for wart-virus antibody determinations. The mean age of the 54 controls. was 38.7 years. The incidence of warts was also estimated in 402 medical students by questionnaire. These students were aged 20-35 years (mean 23 years); 142 were women and 260 were men.

TABLE I-Age distribution of patients with SLE and controls

\begin{tabular}{l|c|c|c|c|c}
\hline \multicolumn{1}{c|}{ Age (years): } & $<30$ & $30-39$ & $40-49$ & $50-59$ & $\geqslant 60$ \\
\hline $\begin{array}{l}\text { Patients with SLE } \\
\text { Control patients }\end{array}$ & 15 & 14 & 12 & 11 & 4 \\
\hline
\end{tabular}

Patient with SLE were examined using the clinical and laboratory methods previously described. ${ }^{5}$ Wart-virus antigen was prepared from surgically removed warts. ${ }^{6}$ Antibodies were measured by immunodiffusion tests using a micromodification of gel double diffusion. ${ }^{6}$ Antibodies were initially measured from undiluted serum, and antibody titres were determined for twofold dilutions of the serum.

The latex test for rheumatoid factor(s) was performed using Hyland's RA test with latex globulin reagent. For the titrations U-microtitre equipment was used. Phosphate buffered saline was used as diluent. The plates were incubated at room temperature for two to three hours before the results were read. Sera giving a positive reaction at a dilution of $1 / 8$ was considered positive.

The significance of the results was evaluated by $\chi^{2}$ tests.

\section{Results}

INCIDENCE OF WARTS AND EFFECT OF TREATMENT

Warts occurred significantly $(P<0.001)$ more often in patients with SLE than in the control patients (table II). The difference was even greater among older patients. Eleven of the 22 patients with SLE aged 45 years or more had warts, whereas only five of the 49 control patients in the same age group had warts $(P<0.001)$. The exact duration of the warts in the patients with SLE could not be determined because not all patients had noticed the warts. Many seemed to have had them for several years, however-in many cases even before SLE was diagnosed.

TABLE II-Prevalence of warts among various age groups in patients with SLE and controls

\begin{tabular}{|c|c|c|c|c|c|c|c|c|}
\hline \multirow[b]{2}{*}{ Age (years): } & \multicolumn{2}{|r|}{$\leqslant 24$} & \multicolumn{2}{|r|}{$25-44$} & \multicolumn{2}{|r|}{$\geqslant 45$} & \multicolumn{2}{|r|}{ Total } \\
\hline & No & $\begin{array}{c}\text { No }\left({ }^{\circ}\right) \\
\text { with } \\
\text { warts }\end{array}$ & No & $\begin{array}{l}\text { No }(\%) \\
\text { with } \\
\text { warts }\end{array}$ & No & $\begin{array}{l}\text { No }(\%) \\
\text { with } \\
\text { warts }\end{array}$ & No & $\begin{array}{l}\text { No }(\%) \\
\text { with } \\
\text { warts }\end{array}$ \\
\hline $\begin{array}{l}\text { Patients with SLE } \\
\text { Patients with } \\
\text { probable SLE }\end{array}$ & 6 & $3(50)$ & $\begin{array}{r}21 \\
7\end{array}$ & $\begin{array}{r}10(48) \\
1(14)\end{array}$ & $\begin{array}{r}16 \\
6\end{array}$ & $\begin{array}{r}10(63) \\
1(17)\end{array}$ & $\begin{array}{l}43 \\
13\end{array}$ & $\begin{array}{r}23(53) \\
2(15)\end{array}$ \\
\hline All patients with SLE & 6 & $3(50)$ & 28 & $11(39)$ & 22 & $11(50)$ & 56 & $25(45)$ \\
\hline $\begin{array}{l}\text { Control patients } \\
\text { Medical students }\end{array}$ & $\begin{array}{r}23 \\
370\end{array}$ & $\begin{array}{l}5(22) \\
60(16)\end{array}$ & $\begin{array}{l}88 \\
32\end{array}$ & $\begin{array}{l}9(10) \\
5(16)\end{array}$ & $\begin{array}{r}49 \\
4\end{array}$ & $5(10)$ & $\begin{array}{l}160 \\
402\end{array}$ & $\begin{array}{l}19(12) \\
65(16)\end{array}$ \\
\hline
\end{tabular}


Altogether 25 of the 56 patients with probable or definite SLE had been or were undergoing corticosteroid treatment when we recorded their warts. Eight of these patients had detectable warts compared with 17 of the 31 patients who were not on corticosteroid treatment (table III). The difference between these two groups was not statistically significant. Seven patients were treated with cytostatic drugs and six patients with antimalarial drugs in addition to corticosteroids. Ten patients were receiving only antimalarial drugs and five of them had warts. Twelve $(57 \%)$ of the 21 patients who were receiving no treatment had warts.

TABLE III-Effect of corticosteroid treatment on incidence of warts in patients with $S L E$

\begin{tabular}{|c|c|c|c|c|c|}
\hline \multirow{2}{*}{ Diagnostic group } & \multirow[b]{2}{*}{$\cdot$} & \multicolumn{2}{|c|}{ Treated } & \multicolumn{2}{|c|}{ Untreated } \\
\hline & & No & $\begin{array}{l}\text { No }(\stackrel{\circ}{\%}) \\
\text { with warts }\end{array}$ & No & $\begin{array}{l}\text { No }(\%) \\
\text { with warts }\end{array}$ \\
\hline $\begin{array}{l}\text { Patients with SLE } \\
\text { Patients with probable SLE }\end{array}$ & $\because$ & $\begin{array}{r}23 \\
2\end{array}$ & $8^{8(35)}$ & 20 & $\begin{array}{r}15(75) \\
2(18)\end{array}$ \\
\hline All patients with SLE .. & $\ldots$ & 25 & $8(32)$ & 31 & $17(55)$ \\
\hline
\end{tabular}

\section{WART-VIRUS ANTIBODIES}

Serum samples were available for determining antibody from 51 patients with SLE, 21 of whom had warts. Twelve of the patients with warts had wart-virus antibodies measurable with the immunodiffusion technique, and 11 of the 30 patients who did not have warts also had antibodies against wart virus. The geometric mean titres were similar in both groups (table IV).

TABLE IV-Wart-virus antibodies in patients with SLE with and without wart

\begin{tabular}{|c|c|c|c|c|}
\hline & & No tested & $\begin{array}{l}\text { No }(\%) \text { with } \\
\text { antibodies }\end{array}$ & $\begin{array}{l}\text { Geometric } \\
\text { mean titre }\end{array}$ \\
\hline $\begin{array}{l}\text { Warts .. } \\
\text { No warts }\end{array}$ & $\begin{array}{ll} & \\
\therefore & \end{array}$ & $\begin{array}{l}21 \\
30\end{array}$ & $\begin{array}{l}12(57) \\
11(37)\end{array}$ & $\begin{array}{l}1 \cdot 3 \\
1.1\end{array}$ \\
\hline
\end{tabular}

Wart-virus antibodies were determined in 54 control patients, six of whom had warts. Significantly more of the controls had wart-virus antibodies than the patients $(P<0.01)$, but the geometric mean titres were not significantly different (table V).

TABLE V-Wart virus antibodies in sera of patients with SLE and controls

\begin{tabular}{|c|c|c|c|c|c|}
\hline & & & No tested & $\begin{array}{l}\text { No (") (o) with } \\
\text { antibodies }\end{array}$ & $\begin{array}{l}\text { Geometric } \\
\text { mean titre }\end{array}$ \\
\hline$\underset{\text { Controls }}{\text { SLE }}$ & & $\because$ & $\begin{array}{l}51 \\
54\end{array}$ & $\begin{array}{l}23(45) \\
40(74)\end{array}$ & $\begin{array}{l}1 \cdot 2 \\
1.7\end{array}$ \\
\hline
\end{tabular}

\section{RHEUMATOID FACTOR AND WARTS}

Rheumatoid factor in the sera of patients with SLE was measured by the latex test. An inverse correlation was found between the rheumatoid factor activity in the sera and the prevalence of warts (table VI). The 26 patients with no rheumatoid factor activity included 15 with warts, while the 25 with activity included only six with warts. This difference was significant at the level of $\mathbf{P}<0.02$.

TABLE VI-Incidence of warts correlated with rheumatoid factor activity in patients with $S L E$

\begin{tabular}{lll|c|c|c} 
& & & & Tested & No $(\%)$ with warts \\
\hline $\begin{array}{llll}\text { Latex test positive } \\
\text { Latex test negative }\end{array}$ & $\cdots$ & $\ldots$ & $\therefore$ & 25 & $6(24)$ \\
& & 26 & $15(58)$
\end{tabular}

\section{Discussion}

Our study showed that cutaneous warts were more common in patients with SLE than in control patients, the difference being especially prominent in older patients. Our series included several elderly patients with SLE and false-positive seroreactions for syphilis. It is well known that they have the more chronic benign form of the disease, which does not necessarily need treatment. ${ }^{2}$ Neither corticosteroid nor antimalarial treatment' seemed to have any effect on the prevalence of warts.

An increased prevalence of generalised severe viral infections, such as herpes simplex and varicella zoster, as well as less severe infections, such as widespread plane warts and molluscae, have been reported in patients undergoing immunosuppressive treatment. ${ }^{2} 8$ The incidence of warts has also been reported to be increased in immunosuppressed allograft recipients ${ }^{9}$ and in patients with some immunodeficiency syndromes, especially a defective cell-mediated immune response. ${ }^{10}$ Like Shelley, ${ }^{11}$ we found a patient with exceptionally large verrucae on the hands. It has also been reported that patients with warts show reduced sensitivity to tuberculin. ${ }^{12}$

The course of viral infections may be regulated either by humoral antibodies or by the cell-mediated immune response. Infections with picornaviruses-for example, poliovirus and certain myxoviruses-are known to be controlled mainly by antibodies whereas infections by pox and herpes viruses and measles are thought to be controlled mainly by cell-mediated immune mechanisms. ${ }^{13}$ Data on viral immunity are still deficient, however. The exact mechanisms by which defects in cell-mediated immunity impair resistance to viral infectionsfor example, in congenital immunodeficiency syndromes or in acquired diseases such as Hodgkin's disease or immunosuppressed patients-are still unknown.

Cell-mediated immunity may protect the host against viral infections in several ways: the cell-mediated response may attract monocytes to the local area of infection, lymphocytes responding to antigens and mitogens may liberate interferon, or sensitised lymphocytes may recognise a virus-specific antigen on the surface of the infected cells and destroy them. ${ }^{13}$ In addition to the direct cell-mediated immunity, thymus-derived lymphocytes ( $T$ cells) are thought to play an important part in the induction and regulation of humoral immune reactions.

Evidence has been accumulating which supports the view that $T$ lymphocytes play a fundamental part in the pathogenesis of SLE. ${ }^{1415}$ Impaired delayed hypersensitivity, ${ }^{1617}$ defective T-cell function, reduced antibody-dependent cell mediated cytotoxicity antilymphocyte antibodies, and antibodies against circulating granulocytes have been detected in patients with SLE. ${ }^{1819}$ The number of T-rosette forming cells in patients with SLE is low. Changes in the $T: B$ cell ratio have been reported to correlate with fluctuations in clinical disease activity, ${ }^{14}{ }^{20}$ and conceivably a reduction in suppressor $T$ cells might permit amplified autoantibody function and also account for impaired delayed hypersensitivity. ${ }^{14}$ Even if patients with SLE have heightened humoral antibody response the opposite has also been reported. ${ }^{21}$

The impairment of immune mechanisms at any level may contribute to the common occurrence of warts in patients with SLE. We have shown that complement-fixing IgG-type wartvirus antibodies contribute to the cure of warts in some patients. ${ }^{22}$ Any type of wart-virus antibodies may have some protective effect against wart-virus reinfections, however, and conversely any deficiency in the antibody response may contribute to the frequency of warts in SLE, which is probably what happened in our series.

In view of earlier reports of viral antibodies associated with SLE, it is interesting that in our patients wart-virus antibodies were less common than in the controls. Decreased amounts of viral antibody against herpes simplex virus have been reported in rheumatoid arthritis and SLE. ${ }^{23}$ Wart disease is in many ways similar to herpes infections: both are chronic infections caused by a DNA virus. Both of these virus groups can also induce tumours. Latent herpes diseases are often converted to 
clinical diseases by, for example, immunosuppressive treatment. A similar situation may exist for warts. Immune reactions are certainly important in this connection, but they are evidently not the only regulating factors. Metabolic changes or regulation at the cellular level may be of importance in these viral diseases. ${ }^{13} 22$

In the present study an inverse correlation between the occurrence of warts and rheumatoid factor was found. Rheumatoid factor can enhance and amplify neutralisation of herpes virus antibodies in the presence of complement. ${ }^{24}$ Similarly, rheumatoid factor might help resistance to wart virus in vivo. This suggests that rheumatoid factor should be considered as an active factor in immune reactions against viral infections.

This study was supported in part by a grant from the Sigrid Jusélius Foundation to Professor Kari Penttinen and a grant from the Finnish Cultural Foundation. The expert technical help of Miss Helena Kainulainen, Mrs Anja Kallionpää, and Miss Kirsi-Marja Pylkkänen is gratefully acknowledged.

\section{References}

1 Staples, P J, et al, Arthritis and Rheumatism, 1974, 17, 1.

2 Dubois, E L (editor), Lupus Erythematosus. Los Angeles, University of Southern California Press, 1974.
${ }^{3}$ Denman, A M, Medical Biology, 1975, 53, 61.

Cohen, A S, et al, Bulletin on the Rheumatic Diseases, 1971, 21, 643.

5 Johansson, E A, Lassus, A, and Salo, O P, Acta Dermatovenereology, 1972, 52, 196.

${ }^{6}$ Pyrhönen, S, and Penttinen, K, Lancet, 1972, 2, 1330.

7 Tuffanelli, D L, Archives of Dermatology, 1972, 106, 553.

8 Roberts, S O B, in Textbook of Dermatology, ed A Rook, D S Wilkinson, and F J G Ebling, p 1908. Oxford, Blackwell, 1972.

${ }^{9}$ Spencer, E S, and Andersen, H K, British Medical fournal, 1970, 3, 251.

${ }^{10}$ Morison, W L, British Fournal of Dermatology, 1975, 92, 625.

11 Shelley, W B, Acta Dermatovenereology, 1972, 52, 33.

12 Brodersen, I, Genner, J, and Brodthagen, H, Acta Dermatovenereology, $1974,54,291$.

13 Allison, A C, Transplantation Reviews, 1974, 19, 3.

${ }^{14}$ Messner, R P, Lindström, F D, and Williams, R C, jun, fournal of Clinical Investigation, 1973, 52, 3046.

15 Stobo, J D, and Loehnen, C P, Mayo Clinic Proceedings, 1976, 51, 479.

${ }_{16}$ Horwitz, D A, Arthritis and Rheumatism, 1972, 15, 353.

17 Hahn, B H, Bagby, M K, and Osterland, C K, The American fournal of Medicine, 1973, 55, 25.

18 Schneider, J, et al, Clinical and Experimental Immunology, 1975, 20, 187.

19 Butler, W T, et al, Arthritis and Rheumatism, 1972, 15, 231.

${ }^{20}$ Rosenthal, C J, and Franklin, E C, Arthritis and Rheumatism, 1975, 18, 207.

${ }^{21}$ Baum, J, and Ziff, M, fournal of Clinical Investigation, 1969, 48, 758.

22 Pyrhönen, S, and Johansson, E A, Lancet, 1975, 1, 592.

${ }^{23}$ Kalliomäki, J L, and Halonen, P, Annals of the Rheumatic Diseases, 1972, 31, 192.

${ }^{24}$ Ashe, W K, et al, Science, 1971, 172, 176.

(Accepted 8 November 1976)

\title{
Atenolol, methyldopa, and chlorthalidone in moderate hypertension
}

\author{
J WEBSTER， T A JEFFERS， D B GALLOWAY， J C PETRIE， N P BARKER
}

British Medical fournal, 1977, 1, 76-78

\section{Summary}

Combined treatment with low doses of different drugs is widely used for moderate hypertension. The effects of atenolol and methyldopa at two dose levels and in combination at the lower doses were studied in patients with moderate hypertension on continuous treatment with chlorthalidone. The mean reduction in standing blood pressures obtained with atenolol 150 and $300 \mathrm{mg} /$ day was about $27 / 17 \mathrm{~mm} \mathrm{Hg}$ and with methyldopa 750 and $1500 \mathrm{mg} /$ day about $28 / 14 \mathrm{~mm} \mathrm{Hg}$. Combined treatment with atenolol $150 \mathrm{mg} /$ day and methyldopa $750 \mathrm{mg} / \mathrm{day}$ for four weeks resulted in a reduction of $38 / 25 \mathrm{~mm} \mathrm{Hg}$. No difference was observed between the effects of the two doses of atenolol or between the two doses of methyldopa. The lower dose of atenolol was better than the lower dose of methyldopa in reducing lying and standing diastolic blood pressures.

These findings show that in patients on continuous treatment with chlorthalidone the addition of atenolol

\footnotetext{
Department of Therapeutics and Clinical Pharmacology, University of Aberdeen AB9 2ZD

J WEBSTER, MRCP, lecturer

T A JEFFERS, MRCP, lecturer

D B GALLOWAY, MRCP, lecturer

J C PETRIE, MRCP, senior lecturer

Imperial Chemical Industries, Macclesfield, Cheshire

N P BARKER, statistician
}

alone or methyldopa alone or of atenolol and methyldopa in combination is effective in the treatment of moderate hypertension.

\section{Introduction}

Methyldopa and diuretics such as chlorthalidone are widely used to treat moderate hypertension. Atenolol is a new cardioselective $\beta$-adrenoceptor antagonist, which is an effective hypotensive agent. No within-patient studies have been carried out to assess the effect of combined treatment with atenolol and methyldopa. We report the findings of a study to assess the hypotensive effects of atenolol and methyldopa alone and in combination in a group of outpatients with moderate hypertension on chlorthalidone treatment.

\section{Patients and methods}

In the procedure we followed patients were invited to participate in the outpatient trial if their morning lying diastolic pressures were over $105 \mathrm{~mm} \mathrm{Hg}$ and under $125 \mathrm{~mm} \mathrm{Hg}$ and all other outpatient and ward blood pressures confirmed persistent increases in blood pressure. ${ }^{1}$ The nature of the trial was explained and all gave their consent.

After discharge from hospital the patients were seen at the hypertension clinic within two weeks. The protocol excluded patients whose lying diastolic blood pressures fell below $100 \mathrm{~mm} \mathrm{Hg}$ after a four-week outpatient run-in period on chlorthalidone treatment and placebo. One $25-\mathrm{mg}$ tablet of chlorthalidone was taken (Hygroton-K-Geigy) in the morning during the run-in period and throughout the study. After the run-in period a double-blind crossover method was used to assess the effects on lying, standing, and post-exercise blood pressure of three treatments, each provided by two identical-looking tablets 